\title{
KRITIK SOSIAL DALAM KUMPULAN CERPEN KOMPAS EDISI SEPTEMBER-NOVEMBER 2016
}

\author{
Siti Hasanah ${ }^{1}$, Irpa Anggriani Wiharja ${ }^{2}$ \\ Universitas Muhammadiyah Tangerang \\ Sitihasana67@gmail.com
}

\begin{abstract}
Abstrak
Penelitian ini bertujuan untuk mendeskripsikan bentuk penyampaian kritik sosial dan masalah sosial dalam kumpulan cerpen Kompas edisi September-November 2016. Objek penelitian ini adalah kumpulan cerpen dari surat kabar Kompas mulai dari edisi September-November 2016. Sumber data penelitian ini terdiri atas dua belas cerpen yang dimuat di koran Kompas mulai dari edisi September-November 2016. Penelitian ini menggunakan pendekatan sosiologi sastra dengan metode analisis isi. Teknik pengumpulan data pada penelitian ini yaitu teknik baca, catat, dan riset kepustakaan. Instrumen penelitian ini adalah peneliti sendiri dengan dibantu tabel analisis bentuk penyampaian kritik sosial dan masalah sosial. Hasil penelitian menunjukkan bahwa (1) bentuk penyampaian kritik sosial terbagi dua, yaitu bentuk penyampaian langsung dan tidak langsung. (2) masalah sosial terbagi menjadi: masalah lingkungan hidup, peperangan, kemiskinan, disorganisasi keluarga, pelacuran, masalah generasi muda, dan kejahatan.
\end{abstract}

Kata kunci : Kritik sosial, cerpen, Kompas

\section{A. Pendahuluan}

Karya sastra lahir dari kejadian yang dialami, dilihat, dan dirasakan oleh pengarang karena cerminan kondisi sosial yang terjadi dalam masyarakat yang dituangkan dalam karyanya. Konsep kebebasan berekspresi sastra ini pula yang menyebabkan karya sastra mengandung gagasan-gagasan bebas yang tidak terikat. Karya sastra terdiri dari tiga genre, yaitu: puisi, prosa, dan drama. Karya sastra yang berbentuk prosa terdapat cerpen. Cerpen merupakan bentuk cerita yang dapat dibaca dalam waktu singkat karena isi ceritanya yang tidak panjang melebihi isi cerita dalam novel. Jika dibaca, biasanya jalan peristiwa di dalam cerpen lebih padat. Cerpen banyak mengangkat masalah sosial yang terjadi di masyarakat. Masalah sosial yang diangkat dalam cerpen mengandung nilai-nilai kehidupan yang sangat berguna bagi pembaca. Sehingga cerita dalam cerpen mampu memberikan makna kehidupan yang berguna bagi pembaca. 
Kritik sosial merupakan salah satu bentuk komunikasi dalam masyarakat yang bertujuan atau berfungsi sebagai kontrol terhadap jalannya suatu sistem sosial atau proses bermasyarakat. Wujud kehidupan sosial yang dikritik dapat bermacam-macam seluas lingkup kehidupan sosial itu sendiri. Adapun tindakan mengkritik dapat dilakukan oleh siapapun. Tindakan mengkritik berupa penyimpangan yang terjadi dalam situasi lingkungan sosial masyarakat. Kritik sosial banyak tersirat dalam cerita-cerita fiksi yang dituangkan melalui surat kabar.

Satu diantaranya cerpen yang dimuat dalam surat kabar Kompas. Surat kabar Kompas merupakan satu di antara surat kabar yang menerbitkan cerpen setiap Minggu. Cerpen-cerpen Kompas tersirat kritik sosial yang ingin disampaikan penulis bagi pembacanya. Seolah-olah cerpen telah menjadi bagian dari kehidupan sehari-hari. Cerpen Kompas menyajikan berbagai cerita yang menyangkut banyak masalah sosial di antaranya: kemiskinan dan kejahatan. Selain itu, disorganisasi keluarga, peperangan, dan pelanggaran terhadap norma-norma masyarakat. Masalah kependudukan, masalah lingkungan hidup, birokrasi, pemecahan masalah sosial, dan perencanaan sosial juga diangkat dalam cerpen Kompas.

Isi cerita dalam kumpulan cerpen Kompas mengisahkan cerita yang sangat berkaitan erat dengan kondisi masyarakat yang terjadi dalam kehidupan sehari-hari. Jalan cerita yang tidak membosankan, membuat pembaca tertarik untuk membacanya. Seperti dalam cerpen Milana dan Sungai Purba, berisi kisah seorang anak yang begitu rindu dengan sungai purba yang jernih itu pun hilang tanpa diketahui penyebabnya. Sungai yang dahulu jernih lambat laun menjadi tercemar akibat ulah manusia. Cerpen Tukang Cukur menceritakan tentang kejadian peperangan yang terjadi di mana-mana dan kekejaman tentara PKI yang membunuh banyak korban. Tentara PKI yang seharusnya melindungi bangsa Indonesia tetapi malah menghancurkan bangsanya sendiri. Cerpen Nalea mengisahkan seorang anak yang dibuang oleh seorang perempuan yang ditaruh dalam kardus dan akhirnya ditemukan oleh seorang pemulung, anak itu diberi nama Nalea. Nalea dibesarkan dalam tumpukan sampah layaknya anak pemulung. Seharusnya anak itu layak mendapat kasih sayang dari orang tua kandungnya. Anak yang tidak berdosa itu akhirnya dibuang karena untuk menutupi aib hasil hubungan gelap. Beberapa penggalan cerita tersebut, dapat ditarik simpulan bahwa terdapat kritik sosial dalam cerpen Kompas edisi September sampai November 2016. 
Kritik sosial berhubungan dengan kondisi sosial masyarakat dan permasalahannya. Kritik sosial dapat dikaji menggunakan pendekatan sosiologi sastra karena pendekatan sosiologi sastra merupakan kaitan karya sastra dengan kondisi masyarakat. Oleh karena itu, peneliti menggunakan pendekatan sosiologi sastra untuk mengkaji kritik sosial yang ada di dalam kumpulan cerpen Kompas edisi SeptemberNovember 2016. Berkait dengan kritik sosial, penelitian ini ditujukan untuk mendeskripsikan bentuk kritik sosial dan masalah sosial dalam kumpulan cerpen Kompas edisi September-November 2016.

\section{B. Kajian Pustaka}

Cerpen merupakan gambaran kehidupan manusia yang dituangkan dalam karya sastra sama seperti karya sastra yang lain. Sesuai dengan kepanjangan dari cerpen yaitu cerita pendek maka cerita ini disajikan secara pendek dengan satu konflik daan tokoh yang terbatas. Nurgiyantoro (2013) mengatakan "Bentuknya yang pendek, cerpen memiliki karakteristik pemadatan dan pemusatan terhadap sesuatu yang dikisahkan" (h. 12).Cerita tidak dikisahkan secara panjang lebar sampai mendetail, tetapi dipadatkan dan difokuskan pada satu permasalahan saja. Hal ini menunjukkan bahwa cerpen hanya menceritakan satu pokok permasalahan saja, sehingga memengaruhi kepadatan isinya.

Cerpen tentulah memiliki ciri khas tersendiri, seperti yang dikemukakan oleh Tarigan (2015):

1. Ciri-ciri utama cerita pendek adalah: singkat, padu, dan intensif.

2. Unsur-unsur utama cerita pendek adalah: adegan, tokoh, dan gerak.

3. Cerita pendek harus mengandung interpretasi pengarang tentang konsepsinya mengenai kehidupan, baik secara langsung maupun tidak langsung.

4. Sebuah cerita pendek harus menimbulkan satu efek dalam pikiran pembaca.

5. Cerita pendek harus menimbulkan perasaan pada pembaca bahwa jalan ceritalah yang pertama menarik perasaan, baru kemudian menarik pikiran.

6. Cerita pendek mengandung detail-detail yang insiden-insiden yang dipilih dengan sengaja, dan yang bisa menimbulkan pertanyaan-pertanyaan dalam pikiran pembaca.

7. Dalam sebuah cerita pendek sebuah insiden yang terutama menguasai jalan cerita. 
8. Cerita pendek harus mempunyai seorang pelaku utama.

9. Cerita pendek bergantung pada (satu) situasi.

10. Cerita pendek memberikan impresi tunggal.

11. Cerita pendek memberikan suatu kebulatan efek (h. 180-181).

Berdasarkan rumusan masalah, penelitian ini menggunakan pendekatan sosiologi sastra yang mengungkap kaitan realitas kehidupan dan cerpen. Ratna (2015) mengatakan "Pemahaman tentang sosiologi sastra adalah analisis karya sastra dalam kaitannya dengan masyarakat, maka model analisis yang dapat dilakukan meliputi tiga macam", sebagai berikut:

1. Menganalisis masalah-masalah sosial yang terkandung di dalam karya sastra itu sendiri kemudian menghubungkannya dengan keadaan yang pernah terjadi.

2. Menemukan hubungan antarstruktur karya sastra dengan model berbahasa dan bernalar.

3. Menganalisis karya dengan tujuan untuk memperoleh informasi tertentu, dilakukan oleh disiplin ilmu tertentu. Model analisis inilah yang akan menghasilkan penelitian dalam karya sastra. (h. 339)

Kritik sosial adalah kritik yang berupaya menanggulangi permasalahan yang ada di masyarakat. Menurut Suyanto (2011), "Kritik sosial adalah salah satu bentuk komunikasi dalam masyarakat yang bertujuan atau berfungsi sebagai kontrol terhadap jalannya suatu sistem sosial atau proses bermasyarakat" (h. 8). Kehadiran kritik sosial menjadi sangat penting dalam kehidupansosial masyarakat karena berfungsi sebagai alat untuk menanggulangi berbagai masalah sosial.

Bentuk penyampaian kritiknya, pengarang menyampaikan kritik secara langsung dan tidak langsung. Nurgiyantoro (2013) membagi bentuk penyampaian pesan atau kritik menjadi dua, langsung dan tidak langsung (h. 460). Bentuk penyampaian langsung identik dengan cara pelukisan karakter tokoh yang bersifat uraian atau penjelasan. Teknik uraian pengarang secara langsung mendeskripsikan perwatakan tokoh-tokoh cerita yang bersifat memberi tahuatau memudahkan pembaca untuk memahaminya. Dilihat dari segi kebutuhan pengarang yang ingin menyampaikan sesuatu kepada pembaca, teknik penyampaian langsung tersebut bersifat komunikatif. 
Artinya, pengarang dengan mudah menguraikan pesannya dan pembaca juga dapat memahami pesan itu dengan mudah pula.

Soetomo (2015) mengatakan bahwa "Masalah sosial adalah sebuah gejala atau fenomena yang muncul dalam realitas kehidupan bermasyarakat" (h. 28). Dalam kehidupan sehari-hari fenomena tersebut hadir bersamaan dengan fenomena sosial yang lain. Olehsebab itu, untuk dapat memahaminya sebagai masalah sosial dan membedakannya dengan fenomena yang lain diperlukan suatu identifikasi. Identifikasi berupa gejala-gejala yang muncul penyebab terjadinya masalah sosial. Soekanto (2015) berpendapat Masalah sosial sesuai dengan sumbernya dapat diklasifikasikan dalam empat kategori:

1. Masalah sosial yang bersumber dari faktor ekonomi, yaitu:kemiskinan, pengangguran, dan sebagainya.

2. Masalah sosial yang bersumber dari faktor biologi, yaitu:penyakit dan sebagainya.

3. Masalah sosial yang bersumber dari faktor psikologi, yaitu: penyakit syaraf, bunuh diri, disorganisasi jiwa, dan sebagainya.

4. Masalah sosial yang bersumber dari faktor kebudayaan, yaitu: persoalan yang menyangkut perceraian, kejahatan, kenakalan anak-anak, konflik rasial, dan keagamaan (h. 314).

\section{Metodologi Penelitian}

Penelitian ini menggunakan pendekatan sosiologi sastra. Pendekatan sosiologi sastra bertolak dari pandangan bahwa sastra merupakan pencerminan kehidupan masyarakat. Melalui sastra, pengarang mengungkapkan tentang suka duka kehidupan masyarakat yang mereka ketahui dengan sejelas-jelasnya. Data dari penelitian ini diambil dari kumpulan cerpen surat kabar Kompas edisi September-November 2016. Ada 12 cerpen yang menjadi sumber data penelitian ini. Sumber data yang diambil untuk penelitian ini adalah cerpen yanterdapat pada kompas edisi September-November 2016, buku-buku, skripsi yang relevan dalam penelitian ini, dan artikel-artikel yang terdapat di internet yang berkaitan dengan objek penelitian ini.

Teknik pengumpulan data dalam penelitian ini yaitu mengumpulkan beberapa cerpen dari surat kabar Kompas setiap edisi yang terbit mulai dari September-November 
2016. Selain itu, teknik pengumpulan data melalui beberapa tahap, yaitu teknik baca, dan teknik catat. Teknik baca dengan cara membaca cerpen dalam surat kabar harian Kompas setiap edisi yang terbit mulai dari September-November 2016 untuk menemukan pokok permasalahan yang akan dikaji dalam penelitian ini. Selain itu, membaca berbagai buku yang berhubungan dengan penelitian ini sebagai referensi dalam meneliti. Teknik catat dengan cara mencatat data yang diperoleh dari hasil membaca, data yang dicatat sesuai dengan keperluan dalam penelitian ini.

Secara umum analisis data memunyai tiga komponen yaitu 1) reduksi data yaitu memilah dan memilih serta memfokuskan hal yang penting dalam fokus penelitian. Dalam penelitian ini, mereduksi data dalam kumpulan cerpen Kompas edisi SeptemberNovember 2016 yang dibaca, diteliti, kemudian dipilih hal yang difokuskan dalam penelitian yaitu bentuk penyampaian kritik sosial dan masalah sosialnya; 2) penyajian data yaitu dalam penelitian kualitatif berupa teks yang diuraikan. Dalam tahap ini, peneliti mendeskripsikan dan menganalisis bentuk penyampaian kritik sosial dan masalah sosial dalam kumpulan cerpen Kompas edisi September-November 2016. Bentuk penyajian data tersebut berupa tabel analisis dan terdapat uraian di dalamnya. Tujuannya, agar mudah memahami dan menarik kesimpulan; 3) menarik simpulan yaitu peneliti menarik kesimpulan yang sejak awal dirumuskan masalahnya yaitu bentuk penyampaian kritik sosial dan masalah sosial dalam kumpulan cerpen Kompas edisi September-November 2016.

\section{Pembahasan}

Pembahasan berisi penjabaran dan penjelasan mengenai temuan penelitian dengan menggunakan kasus-kasus yang terdapat dalam kumpulan cerpen Kompas edisi September-November 2016.

\section{Bentuk Penyampaian Kritik Sosial dalam Kumpulan Cerpen Kompas Edisi}

\section{September-November 2016}

\section{a. Milana dan Sungai Purba}

Bentuk penyampaian kritiknya, pengarang menyampaikan kritik secara langsung dan tidak langsung. Bentuk penyampaian langsung identik dengan cara pelukisan karakter tokoh yang bersifat uraian atau penjelasan. Sedangkan, bentuk penyampaian 
tidak langsung hanya disampaikan tersirat oleh pengarang dalam ceritanya. Dalam hal ini, cerpen Milana dan Sungai Purba hanya terdapat kritik tidak langsung yang disampaikan Ken Hanggara kepada pembaca berkaitan dengan kritik sosial. Seperti kasus yang terdapat dalam kutipan cerpen Milana dan Sungai Purba berikut ini:

Atau, bisa jadi sungai itu hilang oleh karena Tuhan mengeringkan tempat ini pada zaman dahulu kala agar tidak ada lagi yang percaya takhayul keabadian. (paragraf 13)

Kutipan di atas disampaikan Ken Hanggara berupa kritik tidak langsung. Ken Hanggara menyampaikan kritiknya tentang sungai yang hilang karena pada zaman dahulu masih banyak masyarakat yang memercayai sungai mempunyai penunggu. Sungai yang sebagai sumber kehidupan manusia, hilang entah diketahui penyebabnya. Ken Hanggara menyampaikan kritiknya agar manusia menjaga sungai sebaik-baiknya. Sungai bukan untuk dipercayai sebagai tempat yang ada penunggunya. Tetapi, sungai merupakan ladang kehidupan manusia yang keberadaannya harus dijaga. Ken Hanggara menuangkan kritik melalui cerpennya sebagai bentuk penyampaian suaranya yang memarahi seseorang agar tidak lagi percaya bahwa sungai ada penunggunya. Sungai diciptakan sebagai anugerah dari Tuhan untuk kesejahteraan manusia dan digunakan dengan sebaik-baiknya. Bukan sebaliknya, sungai dipercaya ada penunggunya.

\section{b. Nalea}

Kritik langsung dan tidak langsung disampaikan Sungging Raga dalam cerpennya, cerpen Nalea. Cerpen Nalea menjadi suara dalam pikiran pengarang yang mengomentari kehidupan sosial. Melalui kritiknya, pengarang berharap dapat mengatasi masalah sosial yang ada di sekitarnya. Berikut ini kutipan kritik langsung:

Adakah yang lebih menyenangkan melihat beberapa anak kecil tertawa riang yang bahkan giginya belum lengkap, tapi tetap bisa merasa bahagia meskipun kehidupan ini sesungguhnya teramat keras? (paragraf 5)

Sungging Raga menyampaikan kritiknya dalam cerpen Nalea karena ia begitu prihatin dengan kehidupan anak jalanan. Meskipun kerasnya kehidupan yang mereka jalani, tetapi mereka tetap bahagia. Seharusnya mereka mendapatkan pendidikan dan kehidupan yang layak. Namun kenyataannya kehidupan mereka serba pas-pasan. Dengan begitu, mereka selalu saja bahagia tanpa ada rasa kecewa menjalani kerasnya kehidupan. Selain kritik langsung, terdapat juga kritik tidak langsung. Sungging Raga secara tidak langsung menyampaikan pesan nuraninya bahwa kemiskinan hanya sebuah tontonan saja. Pemerintah sebagai lembaga yang berwenang menanggapi masalah 
kemiskinan, hanya sebagai penonton saja. Hal berikut terdapat dalam kutipan berikut ini:

Sementara kemiskinan hanya menjadi obyek dalam acara realita sosial. Sudah miskin, diuji pula apakah jujur dengan kemiskinannya. (paragraf 23)

Kutipan di atas menyampaikan kritik bahwa kemiskinan hanya menjadi hal pembicaraan dalam kehidupan sosial. Bukan suatu masalah sosial yang dicari jalan keluarnya. Pemerintah sebagai lembaga yang seharusnya mengatasi kemiskinan namun kenyataannya mereka menghias diri untuk kepentingan pribadi. Mereka obral janji sanasini untuk memberantas kemiskinan, kenyataannya kemiskinan hanya sebagai objek saja yang tidak pernah ditengok. Akhirnya, kemiskinan hanyalah sebuah objek belaka yang tidak pernah ditarik benang merahnya.

\section{c. Kisah Ganjil Seorang Penggali Kubur}

Sandi Firly menyampaikan kritik langsung dalam cerpennya, Kisah Ganjil Seorang Penggali Kubur. Sebuah kematian yang menjadi misteri. Tak ada satu orang pun yang mengetahui kematiannya. Hanya saja setiap orang mempersiapkan bekal menuju kematian agar dimatikan dalam keadaan yang baik. Seperti kutipan berikut:

"Banyak orang yang mati di saat mengerjakan kebiasaannya. Semoga kita tidak dimatikan dalam kebiasaan yang buruk-buruk." (paragraf 23)

Kutipan di atas mengungkapkan kritik langsung. Sandi Firly mengungkapkan bahwa banyak orang yang mati sesuai dengan kebiasaan yang ia kerjakan. Ia mengajak pembaca semoga dimatikan tidak dalam mengerjakan kebiasaan yang buruk-buruk. Sebagai manusia, sebaiknya mengerjakan hal-hal kebaikan agar dimatikan dalam keadaan yang baik.

\section{d. Telepon dari Istanbul}

Vika Wisnu menyampaikan kritiknya secara langsung, melalui cerpen Telepon dari Istanbul. Vika menyampaikan kritik yang umum terjadi di masyarakat. Seorang ayah yang khawatir sepeninggalnya tidak bisa memberikan warisan kepada anakanaknya. Sesuai dengan kutipan berikut ini:

Dulu, almarhum ayahnya ingin mati dengan meninggalkan banyak warisan. Untuk itu Hayati dikawinkan, karena tinggal dia satu-satunya yang perawan, maharnya lebih besar, cukup untuk ditukar dengan lahan sekitar tiga setengah hektar. Ayah berwasiat, kelak hasilnya harus dibagi rata untuk istri dan tiga anak gadisnya. (paragraf 26) 
Kutipan di atas menggambarkan kekhawatiran seorang ayah yang tidak bisa meninggalkan warisan bagi keluarganya. Hingga akhirnya, anak perawannya yang belum menikah dikawinkan. Alhasil, agar dapat digantikan maharnya dengan hektaran sawah. Dengan begitu, ia dapat meninggalkan warisan bagi anak-istri sepeninggalnya.

Hal tersebut umum terjadi dalam masyarakat. Suami atau ayah yang tidak mempunyai harta yang berkecukupan, khawatir kalau nanti sepeninggalnya, anak dan istrinya tidak dapat menikmati warisan darinya. Berbagai cara ia lakukan agar anakistrinya dapat bahagia menikmati harta waris darinya.

\section{e. Nelayan yang Malas Melepas Jala}

Nelayan yang Malas Melepas Jala mengungkapkan kritik langsung, sebuah cerpen karya Damhuri Muhammad. Damhuri mengungkapkan kritiknya secara langsung yang umum terjadi di masyarakat. Sebuah fenomena yang umum terjadi yaitu dalam hal bersilaturahmi. Kebiasaan bersilaturahmi di masyarakat, umumnya yang lemah datang kepada saudaranya yang kuat, muda kepada yang tua, dan yang paling sering terjadi yang miskin kepada yang kaya. Hal tersebut diungkapkan dalam kutipan berikut ini:

Kenapa yang harus datang berkunjung itu selalu yang lemah kepada yang kuat, yang muda kepada yang tua, dan yang paling sering terjadi adalah yang miskin kepada yang kaya? Pernahkah sekali saja pihak-pihak yang kuat itu beritikad untuk menjenguk saudara lemahnya, yang tua berkenan singgah sejenak di rumah saudara mudanya? (paragraf 7)

Kutipan di atas mengungkapkan kritiknya, hal yang umum terjadi di masyarakat ketika Idul Fitri. Saudara yang satu berkunjung ke rumah saudaranya yang lain untuk bersilaturahmi. Seorang saudara yang lemah datang kepada saudaranya yang gagah, yang muda datang kepada yang tua, dan yang paling lumrah yaitu yang miskin datang kepada saudaranya yang kaya. Seharusnya, sekali-sekali yang kuat datang yang lemah, yang tua datang yang kepada yang muda dan yang paling mengharuskan yaitu yang kaya datang kepada yang miskin. Hal demikian tidak umum terjadi di masyarakat, malah sebaliknya.

Terkadang yang lemah sering datang kepada saudaranya yang kuat untuk meminta belas kasih dari saudaranya. Namun, yang kuat tidak pernah ada keinginan sedikit pun mengunjungi saudaranya yang lemah hanya sekadar melihat keadaan saudaranya.Hal yang paling sering terjadi, saudara yang miskin berkunjung kepada saudaranya yang kaya. Pernahkah saudara yang kaya ada keinginan untuk berkunjung kepada saudaranya yang miskin. Kejadian tersebut tidak akan terjadi karena yang 
miskin menganggap tidak mungkin dikunjungi saudaranya yang kaya. Maka dari itu, selalu saja yang miskin selalu lebih dahulu berkunjung ke saudaranya yang kaya.

\section{f. Istana Tembok Bolong}

Seno Gumira Ajidarma dalam cerpennya, Istana Tembok Bolong. Mengungkapkan kritiknya secara tidak langsung. Seno mengungkapkan kritiknya yang terjadi di masyarakat bagaimana uang bisa membeli segalanya. Orang yang memunyai banyak uang bisa sesukanya mendapatkan yang ia mau. Seperti kutipan berikut ini:

"Kalau masih memaksa juga kamu boleh bermain korek api. Dengan uangmu kamu bisa menyalakan batang korek api sepuluh kali”. (paragraf 25)

Kutipan di atas mengungkapkan kritik tidak langsung. Kritik yang tidak mudah dipahami tanpa memahami maknanya secara mendalam. Kritik tersebut diungkapkan Seno, "Kalau masih memaksa juga kamu boleh bermain korek api. Seno mengungkapkan seseorang yang ingin menginginkan jabatan. Jabatan yang tidak kekal, sewaktu-waktu dapat mencelakakan dirinya apabila ia tidak amanah memegang jabatannya. Dengan uangmu kamu bisa menyalakan batang korek api sepuluh kali”, seseorang yang memunyai banyak uang dapat melakukan apa saja dengan uangnya. Satu di antaranya menginginkan jabatan agar dapat dihormati dan disegani orang lain. Bahkan, ketika jabatannya habis masa waktunya. Ia dapat memegang kembali jabatannya karena dengan uangnya yang banyak ia dapat melakukan segala cara untuk memangku kembali jabatannya.

\section{g. Profesor Bermulut Runcing}

Melalui cerpen Profesor Bermulut Runcing, Rizqi Turama mengungkapkan kritiknya. Rizqi mengungkapkan kritik secara tidak langsung. Kritik yang diungkapkan yaitu kritik terhadap seorang profesor yang selalu disegani orang lain karena banyaknya ilmu yang ia milikinya. Seorang yang sudah memunyai gelar profesor tentulah sudah bisa disebut orang yang jenius. Keilmuannya sudah tidak diragukan lagi. Berikut ini kutipan yang berisikan kritik:

Dengan menjadi profesor, ia bisa mendatangi berbagai tempat. Memberikan kuliah sana-sini. Mendapatkan sambutan hangat di mana-mana-sebab ada banyak orang yang mau menjilati ia sampai ke getah-getah terakhir. (paragraf 13)

Kutipan di atas diungkapkan bagiamana seseorang yang sudah memunyai gelar profesor dapat memanfaatkan ilmu yang ia miliki. Ia dapat mendatangi berbagai tempat 
atau memberikan keilmuannya dimana pun. Kritik secara tidak langsung diungkapkan Rizqi: Mendapatkan sambutan hangat di mana-mana-sebab ada banyak orang yang mau menjilati ia sampai ke getah-getah terakhir. Maksud kritik yang diberikan yaitu seorang profesor selalu disegani orang lain dimana pun. Sebab ada banyak orang yang mau menjilati ia sampai ke getah-getah terakhir. Kata menjilati diungkapkan secara tidak langsung, maksudnya seorang profesor apabila memberikan materi dalam seminar yang mengangkat suatutema pasti banyak orang yang ingin mendapatkan keilmuannya. Banyak yang menanyakan kepadanya mengenai ini dan itu agar dapat mendapatkan jawaban sejelas-jelasnya mengenai tema yang diangkat sampai keakar-akarnya.

\section{Masalah Sosial dalam Kumpulan Cerpen Kompas Edisi September-}

\section{November 2016}

\section{a. Milana dan Sungai Purba}

Masalah sosial adalah realita kehidupan yang nyata terjadi dalam masyarakat. Masalah sosial harus diatasi agar terwujudnya perubahan-perubahan yang lebih baik. Melalui cerpen Milana dan Sungai Purba, Ken Hanggara memaparkan masalah sosial lingkungan hidup yang tercemar akibat ulah tangan manusia. Seperti yang terdapat dalam kutipan berikut ini:

Waktu itu kami ke taman ini, tempat yang dulu pernah dialiri sungai purba, beribu-ribu tahun silam, suatu masa yang dapat kulihat jelas, sejelas ikan-ikan di dalam akuarium baru. Bagaimana aku melakukannya, aku tidak tahu. Penglihatan itu suka muncul tiba-tiba dan aku semakin ingin membuktikan paling tidak kepada satu orang saja, bahwa sungai purba itu bukan sekadar legenda. (paragraf 4)

Kutipan di atas menjelaskan sungai yang dahulunya jernih bagai melihat ikanikan dalam aquarium tetapi lambat laun sungai itu hilang akibat ulah tangan manusia yang mencemari lingkungan. Sungai yang seharusnya jernih hingga anak-cucu. Namun, sungai menjadi bahan pembuangan segala jenis sampah. Entah itu sampah rumah tangga, limbah pabrik, bahkan kotoran manusia. Pada akhirnya, sungai menjadi tercemar dan kejernihannya sudah tidak bisa dilihat lagi.

\section{b. Nalea}

Masalah sosial dalam kehidupan sosial merupakan masalah yang seharusnya diatasi. Satu di antaranya masalah kemiskinan. Kemiskinan sudah menjadi hal yang sering diperbincangkan. Namun, kenyataannya kemiskinan makin bertambah setiap 
tahunnya. Bukan suatu masalah sosial yang dicari jalan keluarnya. Sungging Raga dalam cerpennya Nalea, menyampaikan masalah sosial kemiskinan. Berikut ini masalah kemiskinan yang dikutip:

Siang itu, Nalea sedang duduk di pinggiran taman kota. Seperti biasa, ia berkumpul dengan bocah sebayanya dengan pakaian lusuh. (paragraf 5)

Kutipan di atas menyampaikan suatu masalah sosial mengenai kemiskinan. Anak-anak yang seharusnya dapat hidup layak dan dapat menikmati kehidupan ini dengan layak. Namun, mereka hidup serba kekurangan. Seharusnya hal ini menjadi PR penting pemerintah. Kemiskinan harus dibabat habis agar seluruh rakyat dapat hidup sejahtera.

\section{c. Kisah Ganjil Seorang Penggali Kubur}

Masalah kemiskinan diungkapkan dalam cerpen Kisah Ganjil Seorang Penggali Kubur karya Sandi Firly. Kehidupan miskin seorangsuami menjadidampak bagi anakistri. Anak yang seharusnya mendapatkan kehidupan yang layak. Namun karena orang tua miskin, mau tidak mau seorang anak mengikuti jejak orag tuanya. Seperti kutipan berikut ini:

Sekarang ia benar-benar telah menjadi seperti bapaknya, seorang penggali kubur. Hingga usianya mencapai empat puluh tahun sekarang ini. (paragraf 16)

Kutipan di atas merupakan masalah kemiskinan. Orang tua seorang penggali kubur dengan pendapatan pas-pasan. Kemiskinan menjadi masalah sosial hingga berdampak kepada anak-anak. Orang tua tidak mampu memberikan pendidikan kepada anak-anaknya hingga akhirnya anak pun mengikuti jejak orang tuanya.

Masalah sosial yang banyak ditemukan dalam kehidupan sosial. Orang tua yang tidak sanggup membiayai pendidikan anak-anaknya. Akhirnya, anak menjadi pengikut jejak pekerjaan orang tuanya untuk memenuhi kebutuhan hidup yang serba pas-pasan. Seharusnya hal ini menjadi peran pemerintah agar masalah kemiskinan tidak terusmenerus bertambah. Pemberian pendidikan gratis yang diberikan sesuai dengan kebutuhan masyarakat menjadi satu di antara berkurangnya masalah kemiskinan.

\section{d. Telepon dari Istanbul}

Telepon dari Istanbul, sebuah cerpen karya Vika Wisnu. Sebuah cerpen yang menggangkat masalah sosial disorganisasi keluarga. Disorganisasi keluarga terjadi karena seorang suami gagal memenuhi kewajibannya sesuai dengan peranan sosialnya. Disorganisasi keluarga dalam cerpen Telepon dari Istanbul terjadi karena seorang suami 
yang gagal memenuhi kewajibannya dan akhirnya meninggalkan istrinya. Seperti kutipan berikut ini:

Aku ingat namamu, aku pernah selama tiga tahun menjadi suamimu, kita kawin kontrak disaksikan Ayahmu dan penghulu Desa Kalisaf Kecamatan Rembang tujuh belas tahun lalu. Tapi ikatan kerjaku dengan perusahaan sepatu itu tak diperpanjang, mereka mencari tenaga lokal yang lebih murah. Aku ingat kau mencegahku pulang ke negeriku dan memintaku menetap. (paragraf 16)

Kutipan di atas mengungkapkan masalah sosial terjadinya disorganisasi keluarga. Seorang laki-laki perantauan mendapat ikatan kerja di Desa Kalisaf, Rembang. Laki-laki tersebut kawin kontrak dengan gadis desa. Namun, ikatan kerja laki-laki tersebut tidak diperpanjang hingga akhirnya ia meninggalkan istrinya dan kembali ke negerinya. Sebagai seorang suami, ia gagal memenuhi kewajibannya.

\section{a. Nelayan yang Malas Melepas Jala}

Damhuri Muhammad mengungkapkan dalam cerpennya, Nelayan yang Malas Melepas Jala. Dalam cerpennya, Damhuri mengungkapkan masalah sosial terjadinya disorganisasi keluarga. Disorganisasi keluarga yang diungkapkan dalam cerpennya yaitu terjadinya hubungan perselingkuhan. Suami sebagai kepala keluarga gagal menjaga hubungan pernikahannya dengan berselingkuh. Seperti kutipan berikut ini:

Rencananya melacak kembali kesendirian yang lenyap sejak ia berkeluarga, dan keberuntungan tak terduga sejak ia bertemu perempuan yang ternyata juga pecandu kesunyian, hingga terbangunlah hubungan gelap yang amat mendebarkan, sekaligus rawan-ketahuan itu. (paragraf 15)

Kutipan di atas mengungkapkan masalah disorganisasi keluarga. Suami sebagai kepala keluarga mencari wanita lain karena merasa kesepian walaupun ia sudah memunyai istri. Hingga diam-diam ia berselingkuh dengan wanita lain yang juga merasa kesepian dalam hubungan dengan suaminya. Masalah disorganisasi keluarga terjadi akibat suami berselingkuh karena istri kurang menjaga keharmonisan hubungan dengan suaminya. Sebab itulah, suami mencari pelipur kesepiannya dengan wanita lain.

Hubungan gelap antara suami yang sudah memunyai istri dan istri yang sudah memunyai suami banyak terjadi di masyarakat. Sebuah masalah sosial diorganisasi keluarga yang sebaiknya dihilangkan. Namun, di daerah perkotaan banyak terjadi perselingkuhan dikarenakan suami kurang mendapat perhatian dari istrinya. Walaupun suami sudah memunyai istri, ia selalu merasa kesepian. Hal tersebut terjadi misal: istri yang sibuk brkerja hingga larut malam sehingga perhatian yang diberikan suami 
berkurang. Hal itulah yang menjadikan suami mencari pelipur kesunyiannya dengan berselingkuh pada wanita lain.

\section{e. Istana Tembok Bolong}

Masalah sosial dalam hal kejahatan banyak terjadi di masyarakat. Kejahatan disebabkan karena kondisi sosial yang mendorong seseorang berperilaku jahat. Seno Gumira Ajidarma dalam cerpennya Istana Tembok Bolong, mengungkapkan masalah kejahatan. Kejahatan yang diungkapkan yaitu seorang perempuan telah berbuat jahat dengan memengaruhi jiwa anak-anak untuk menghisap rokok di usia dini. Seperti kutipan berikut ini:

"Kawan-kawanmu semuanya juga mau," kata perempuan itu, setelah menghisap rokok cap Admiral kuat-kuat sampai letik baranya beterbangan ditiup angin, "tapi aku tidak akan menambah dosa-dosaku yang sudah bertumpuk dengan merusak jiwa anak-anak". (paragraf 23)

Kutipan di atas mengungkapkan seorang perempuan yang sudah banyak memengaruhi jiwa anak-anak namun ia tidak mau mengulangi perbuatannya lagi. Sudah banyak kejahatan yang ia lakukan, menyuruh anak-anak menghisap rokok saat usianya masih sangat dini. Apabila seseorang menjadi jahat, hal itu disebabkan dipelajari dalam interaksi dengan orang lain yang berperilaku jahat dengannya. Kejahatan tersebut dapat diatasi dengan pemberian nasihat-nasihat yang dapat mendorongnya agar tidak berperilaku jahat lagi.

\section{f. Profesor Bermulut Runcing}

Masalah sosial bermacam-macam masalah yang terjadi dalam kehidupan sosial. Disorganisasi keluarga merupakan satu di antara masalah sosial yang umum terjadi dalam lingkungan sosial. Satu di antara terjadinya disorganisasi keluarga yaitu seorang suami yang gagal memenuhi perannya sebagai kepala keluarga dan ia tidak berusaha mempertahankan kerukunan keluarganya. Satu di antaranya seorang suami yang menghianati pernikahannya dengan melakukan perselingkuhan. Melalui cerpen Profesor Bermulut Runcing, Rizqi Turama mengungkapkan masalah sosial terjadinya disorganisasi keluarga. Disorganisasi keluarga yang diungkapkan Rizqi yaitu perselingkuhan. Seorang wanita bergelar doktor yang diselingkuhi suaminya, ketika itu ia mendapati suaminya sedang berselingkuh dengan wanita lain. Seperti kutipan berikut ini: 
Jauh hari sebelum profesor kita menjadi profesor dan baru saja lulus sebagai doktor, tujuh tahun lalu tepatnya, ia mendapati suaminya berselingkuh. (paragraf 1)

Kutipan di atas mengungkapkan masalah sosial terjadinya disorganisasi keluarga. Suami sebagai kepala keluarga mengkhianati pernikahannya yaitu melakukan perselingkuhan. Seharusnya suami sebagai kepala keluarga mempertahankan keharmonisan hubungan pernikahannya bukan mengkhianatinya. Suami yang selingkuh dengan wanita lain disebabkan istri yang tidak membuat suami betah di rumah. Faktor istri yang bermacam-macam yaitu istri yang tidak bisa mengurus rumah, tidak bisa merawat diri, dan tidak bisa memanajemen keuangan rumah tangga. Faktor-faktor itulah yang mendorong suami mencari wanita lain karena istri yang tidak bisa menempati perannya sesuai dengan keinginan suaminya.

\section{E. Simpulan}

Berdasarkan temuan penelitian dan pembahasan yang telah diuraikan, penelitian mengenai kritik sosial kumpulan cerpen Kompas edisi September-November 2016 dapat disimpulkan yaitu bentuk penyampaian kritik sosial yang terbagi menjadi dua: (1) bentuk penyampaian kritik langsung, dan (2) bentuk penyampaian tidak langsung yaitu pada cerpen yang berjudul Milana dan Sungai Purba, Nalea, Kisah Ganjil Seorang Penggali Kubur, Telepon dari Istanbul, Nelayan yang Malas Melepas Jala, Istana Tembok Bolong, dan Profesor Bermulut Runcing. Masalah sosial dalam kumpulan cerpen Kompas edisi September-November 2016 yaitu: masalah lingkungan hidup dalam cerpen Milana dan Sungai Purba, Nalea, Kisah Ganjil Seorang Penggali Kubur, Telepon dari Istanbul, Nelayan yang Malas Melepas Jala, Istana Tembok Bolong, dan Profesor Bermulut Runcing.

\section{F. Daftar Pustaka}

Nurgiyantoro, Burhan. (2013). Teori Pengkajian Fiksi. Yogyakarta: UGM Press.

Ratna, Nyoman Kutha. (2015). Teori, Metode, dan Teknik Penelitian Sastra. Yogyakarta: Pustaka Pelajar.

Seotomo. (2015). Masalah Sosial dan Upaya Pemecahannya. Yogyakarta: Pustaka Pelajar.

Soekanto, Soerjono. (2015). Sosiologi Suatu Pengantar. Jakarta: Rajawali Press. 
Lingua Rima: Jurnal Pendidikan Program Studi Bahasa dan Sastra Indonesia Vol. 7 No. 1 Januari 2018

Suyatno. (2011). Pendidikan Karakter Berbasis Sastra. Jakarta: Kementrian Pendidikan Nasional.

Tarigan, Henry Guntur. (2015). Prinsip-prinsip Dasar Sastra. Bandung: Angkasa. 